\title{
Evaluation of Ranking Accuracy in Multi-Criteria Decisions
}

\author{
Edmundas Kazimieras ZAVADSKAS, Algimantas ZAKAREVICIUS, \\ Jurgita ANTUCHEVICIENE \\ Vilnius Gediminas Technical University \\ Sauletekio al. 11, LT-10223, Vilnius-40, Lithuania \\ e-mail:edmundas.zavadskas@adm.vtu.lt,algimantas.zakarevicius@ap.vtu.lt, \\ jurgita.antucheviciene@st.vtu.lt
}

Received: March 2006

\begin{abstract}
The paper analyses the problem of ranking accuracy in multiple criteria decision-making (MCDM) methods. The methodology for measuring the accuracy of determining the relative significance of alternatives as a function of the criteria values is developed. An algorithm of the Technique for the Order Preference by Similarity to Ideal Solution (TOPSIS) that applies criteria values' transformation through a normalization of vectors and the linear transformation is considered. A computational experiment is presented, to compare the results of a multiple criteria analysis and the ranking accuracy in a particular situation.
\end{abstract}

Key words: decision-making, multi-criteria optimisation, ranking accuracy, TOPSIS, vector normalization, linear normalization, standard deviation, confidence interval, construction management.

\section{Introduction}

Contemporary optimisation problems are characterized by a diversity of structures and processes, incommensurable variables, conflicting development objectives and constraints. Therefore, multi-criteria optimisation techniques seem to be an appropriate tool in ranking or selecting the proper alternatives from a set of available options in the presence of multiple, and usually conflicting criteria.

Multiple criteria decision-making (MCDM) frameworks vary from simple approaches based on a small amount of data to methods based on mathematical simulation and programming techniques, requiring extensive information for each criterion and on a decision-maker's preferences. A large number of methods have been developed for solving multi-criteria problems. The methodology and classification of the above methods has been presented in several publications, namely: Hwang and Yoon, 1981; Zeleny, 1982; Chen and Hwang, 1991; Schneeweiss, 1991; Zimmermann and Gutsche, 1991; Guitouni and Martel, 1998; Triantaphyllou, 2000; Kalika and Rossinsky, 2003; Brauers, 2004; Zavadskas et al., 2004; Greening and Bernow, 2004; Figueira et al., 2005; Kaklauskas et al., 2005, 2006. However, the problem of choosing an appropriate method in a particular situation still exists. A number of researchers have proved that there are some ranking 
differences between the various methods. The significance of alternatives and their priority order vary, depending on the decision-making technique that is used. Comparative assessments of MCDM methods have been made and computational experiments (Dzemyda and Petkus, 2001) as well as case studies have been presented by Dzemyda and Saltenis (1994); Raju and Pillai (1999); Sarkis (2000), etc.

The main goal of the present research is to evaluate the ranking accuracy in multicriteria problems. The methodology for measuring the accuracy of the determined relative significance of the alternatives as a function of the initial criteria values has been developed and described in this paper. The difference in the relative significance of the alternatives that can be considered statistically insignificant within the accepted calculation accuracy limits was assessed.

In this paper, an algorithm of the Technique for Order Preference by Similarity to Ideal Solution (TOPSIS) is analysed. TOPSIS was developed by Hwang (Hwang and Yoon, 1981) and widely applied by other researchers (Deng et al., 2000; Tsaur et al., 2002; Opricovic and Tzeng, 2002; Cheng et al., 2003; Montanari, 2004; Tong et al., 2004; Tzeng et al., 2005, etc.). The authors of this paper have been applying the TOPSIS method for construction solutions since 1986 (Fiedler et al., 1986; Zavadskas et al., 2001; Zavadskas et al., 2002; Vilutiene and Zavadskas, 2003; Zavadskas and Antucheviciene, 2004).

A matrix containing alternatives and the criteria, where usually, the criteria have different dimensions that complicate their comparison that is needed for determining their effectiveness, represents all multi-criteria problems. In order to avoid the difficulties caused by their different dimensions, a transformation (or normalization) of the criteria values is used. A number of theories for transformation through a normalization of vectors, linear transformation and non-linear transformation have been developed by Jüttler (1966); Körth (1969); Weitendorf (1976); Hwang and Yoon (1981); Peldschus et al. (1983); Peldschus and Zavadskas (2005). The application of the above theories in different MCDM methods has been analysed in various scientific publications. It has been proved that the choice of criteria or weight transformation theory may affect the solution (Gogus and Boutcher, 1997; Lin and Sharp, 1999; Pöyhönen et al., 2001; Peldschus, 2001; Dejus, 2002; Zavadskas et al., 2003; Kettani et al., 2004; Saaty, 2006; Opricovic and Tzeng, 2004).

According to Hwang and Yoon (1981), TOPSIS uses vector normalization. Later, it was proposed to employ linear normalization in the same multi-criteria method (Lai and Hwang; 1994). Taking into consideration the notion that normalization procedures may affect the final MCDM solution, the TOPSIS algorithm that apply the criteria values' transformation through a normalization of vectors and the linear transformation are compared in this research paper.

A computational experiment is presented to compare the results of multiple criteria analysis by using two criteria values' transformation methods in a particular situation. The standard deviation of relative significance of the alternatives and confidence intervals are measured according to the developed methodology. The accuracy of the TOPSIS method that is based on linear and vector normalization for the criteria values is determined by applying the proposed methodology. 


\section{Methodology for Measuring the Accuracy of MCDM Results}

\subsection{Relative Significance of Alternatives as a Function of Criteria Values}

The result of a multi-criteria analysis (the relative significance of an alternative) is a function of the criteria values. The values of the initial criteria are arguments of the result function. Usually, in the process of measurement some errors occur in the criteria values of the initial multi-criteria decision matrix. Consequently, a precise solution can hardly be obtained. The alternatives can be properly ranked only if the accuracy of determining the relative significance of alternatives is measured.

Assuming that errors of determining the initial criteria values are stochastic, the methods of the theory of probability and mathematical statistics can be applied for evaluating the accuracy of the results of a multi-criteria analysis. The variance $\sigma^{2}$ or standard deviation $\sigma$ is a measure of dispersion in the distribution.

Suppose, there is the function:

$$
y=\varphi\left(x_{1}, x_{2}, \ldots, x_{n}\right)
$$

The standard deviations of the function's arguments (9) are $\sigma\left(x_{1}\right), \sigma\left(x_{2}\right), \ldots, \sigma\left(x_{i}\right)$, $\ldots, \sigma\left(x_{n}\right)$. Assuming that the standard deviations of arguments $x_{i}$ are statistically unconnected, the variance of function $y$ is determined as follows (Ross, 2004):

$$
\sigma^{2}(y)=\sum_{i=1}^{n}\left(\frac{\partial \varphi}{\partial x_{i}}\right)^{2} \sigma^{2}\left(x_{i}\right)
$$

where $\frac{\partial \varphi}{\partial x_{i}}$ is a partial derivative of a function in respect of every argument.

In the case of a multiple function

$$
y=\varphi(u, v)
$$

where $u=f_{1}(x), v=f_{2}(x)$, the variance of the function is determined as follows:

$$
\sigma^{2}(y)=\left(\frac{\partial \varphi}{\partial u} \cdot \frac{\mathrm{d} u}{\mathrm{~d} x}\right)^{2} \sigma^{2}(x)+\left(\frac{\partial \varphi}{\partial v} \cdot \frac{\mathrm{d} v}{\mathrm{~d} x}\right)^{2} \sigma^{2}(x) .
$$

Successive transformations of the initial data, according to particular functional relations, are performed in the process of multi-criteria analysis. Consequently, when evaluating the accuracy of the final results (the relative significance of alternatives) it is possible to measure the accuracy of the result in conformity with the described common theory of evaluating the accuracy of the function arguments, performing successive transformation of the initial data and calculating the variance as well as the standard deviation.

In this paper, the methodology is developed and an example of its application is presented. The relative significance of the alternatives of buildings' redevelopments is determined by applying TOPSIS and two methods of criteria values' normalization. The accuracy of the obtained results is also measured. 


\subsection{Algorithm of TOPSIS Based on Two Criteria Values' Normalization Methods}

The basic concept of the TOPSIS method (the Technique for Order Preference by Similarity to Ideal Solution) is that the selected alternative should have the shortest distance from the ideal solution and the longest distance from the negative-ideal solution, in a geometrical sense. The method evaluates the decision matrix, which refers to $n$ alternatives that are evaluated in terms of $m$ criteria. The member $i j$ denotes the performance measure of the $j$ th alternative in terms of the $i$ th criterion.

The first step of the procedure of every multiple criteria decision-making method is to calculate the normalized decision matrix. Considering the opinion, that there are normalization procedures with effects on the final MCDM result, two normalization methods were used in the TOPSIS technique. The classical TOPSIS uses vector normalization (Hwang and Yoon, 1981; Fiedler et al., 1986; Zavadskas et al., 1994; Triantaphyllou, 2000):

$$
r_{i j}=\frac{a_{i j}}{\sqrt{\sum_{j=1}^{n} a_{i j}^{2}}}
$$

where $r_{i j}$ is the normalized value, $i=1,2, \ldots, m ; j=1,2, \ldots, n$.

Lai and Hwang (1994) introduced linear normalization into the TOPSIS:

$$
r_{i j}=\frac{a_{i j}}{\max _{j} a_{i j}-\min _{j} a_{i j}} .
$$

The weighted normalized value $\nu_{i j}$ is calculated as

$$
\nu_{i j}=q_{i} r_{i j}, \quad i=1,2, \ldots, m, \quad j=1,2, \ldots, n,
$$

where $q_{i}$ is the weight of $i$ th criterion.

The ideal and the negative-ideal solutions denoted respectively as $A^{*}$ and $A^{-}$are defined as follows (Hwang and Yoon, 1981; Fiedler et al., 1986; Zavadskas et al., 1994; Triantaphyllou, 2000):

$$
\begin{aligned}
& A^{*}=\left\{\nu_{1^{*}}, \nu_{2^{*}}, \ldots, \nu_{m^{*}}\right\}, \quad \text { for } i=1,2, \ldots, m, \\
& A^{-}=\left\{\nu_{1^{-}}, \nu_{2^{-}}, \ldots, \nu_{m^{-}}\right\}, \quad \text { for } i=1,2, \ldots, m,
\end{aligned}
$$

where $\nu_{i^{*}}=\max _{j} \nu_{i j}, \nu_{i^{-}}=\min _{j} \nu_{i j}, i=1,2, \ldots, m ; j=1,2, \ldots, n$, if the $i$ th criterion represents a benefit;

$\nu_{i^{*}}=\min _{j} \nu_{i j}, \nu_{i^{-}}=\max _{j} \nu_{i j}, i=1,2, \ldots, m ; j=1,2, \ldots, n$, if the $i$ th criterion represents a cost.

The Euclidean distance method is then applied to measure the distances of each alternative from the ideal solution $S_{j^{*}}$ and negative-ideal solution $S_{j^{-}}$:

$$
S_{j^{*}}=\sqrt{\sum_{i=1}^{m}\left(\nu_{i j}-\nu_{i^{*}}\right)^{2}}, \quad \text { for } j=1,2, \ldots, n
$$




$$
S_{j-}=\sqrt{\sum_{i=1}^{m}\left(\nu_{i j}-\nu_{i-}\right)^{2}}, \quad \text { for } j=1,2, \ldots, n \text {. }
$$

The relative closeness of an alternative $A_{j}$ to the ideal solution $A^{*}$ (the relative significance of an alternative) is defined as follows:

$$
C_{j^{*}}=\frac{S_{j-}}{S_{j^{*}}+S_{j-}}
$$

where $1 \geqslant C_{j^{*}} \geqslant 0$ and $j=1,2, \ldots, n$.

The best alternative can be found according to the preference order of $C_{j^{*}}$.

\subsection{Algorithm for Measuring the Ranking Accuracy of Alternatives by Applying} TOPSIS, Based on Two Criteria Values' Normalization Methods

The initial data. According to the described algorithm (Subsection 2.2.), $a_{i j}$ is the value of the criterion evaluating the alternative; $i=1,2, \ldots, m ; j=1,2, \ldots, n$ ( $m$ is the number of criteria, $n$ is the number of alternatives).

Assuming that the measurement's accuracy of the same initial criterion value in each alternative is the same, then the standard deviations of the criteria values are identical and equal to $\sigma\left(a_{i}\right), i=1,2, \ldots, m$.

Accuracy of normalized criteria values. In order to avoid the influence of various dimensions of the criteria and different measurement scales on the results of ranking, a transformation (or normalization) of the criteria values is used. In a process of normalization, the initial measured values of the criteria are transformed into non-dimensional relative values, with proportionality of values remaining unchanged. Accordingly, the normalizing multiplier is considered to be a fixed value, representing the scale of transformation of the initial data.

Then, the derivatives of normalized values in the case of vector normalization (5) are as follows:

$$
\frac{\partial r_{i j}}{\partial a_{i j}}=\frac{1}{\sqrt{\sum_{j=1}^{n} a_{i j}^{2}}}
$$

and the variance of normalized values is calculated as

$$
\sigma^{2}\left(r_{i j}\right)=\frac{\sigma^{2}\left(a_{i}\right)}{\sum_{j=1}^{n} a_{i j}^{2}} .
$$

Similar to the above-described assumptions, in the case of linear normalization (6), the variance is defined as follows:

$$
\sigma^{2}\left(r_{i j}\right)=\frac{\sigma^{2}\left(a_{i}\right)}{\left(a_{i}^{*}-a_{i}^{-}\right)^{2}} .
$$


Whereas the values of criteria are positive numbers, by comparing denominators of Eq. 14 and Eq. 15 we get:

$$
\sum_{j=1}^{n} a_{i j}^{2}>\left(a_{i}^{*}-a_{i}^{-}\right)^{2}
$$

therefore, the values of the normalized criteria based on linear normalization are assessed to be less accurate compared to the values obtained by the method based on vector normalization of the criteria values.

Accuracy of criteria values of the weighted normalized matrix. The weighted normalized decision-making matrix is calculated by multiplying the elements of the normalized matrix by the appropriate criteria weights (7). Consequently, the derivatives of the weighted normalized values and the variances are determined as follows:

$$
\begin{aligned}
& \frac{\partial \nu_{i j}}{\partial r_{i j}}=q_{i}, \\
& \sigma^{2}\left(\nu_{i j}\right)=q_{i}^{2} \sigma^{2}\left(r_{i j}\right) .
\end{aligned}
$$

Accuracy of determining a distance of each alternative from the ideal and the negative-ideal solution. The variance of the distance from the ideal solution is determined from Eq. 10:

$$
\begin{aligned}
\frac{\partial S_{j^{*}}}{\partial \nu_{i j}} & =\frac{\nu_{i j}-\nu_{i^{*}}}{\sqrt{\sum_{i=1}^{m}\left(\nu_{i j}-\nu_{i^{*}}\right)^{2}}}, \\
\frac{\partial S_{j^{*}}}{\partial \nu_{i^{*}}} & =-\frac{\nu_{i j}-\nu_{i^{*}}}{\sqrt{\sum_{i=1}^{m}\left(\nu_{i j}-\nu_{i^{*}}\right)^{2}}} .
\end{aligned}
$$

Since $\sigma\left(\nu_{i j}\right)=\sigma\left(\nu_{i^{*}}\right)$,

$$
\sigma^{2}\left(S_{j^{*}}\right)=2 \frac{\sum_{i=1}^{m}\left[\left(\nu_{i j}-\nu_{i^{*}}\right)^{2} \sigma^{2}\left(\nu_{i j}\right)\right]}{\sum_{i=1}^{m}\left(\nu_{i j}-\nu_{i^{*}}\right)^{2}} .
$$

In a similar way, the variance of the distance from the negative-ideal solution is determined as follows:

$$
\sigma^{2}\left(S_{j-}\right)=2 \frac{\sum_{i=1}^{m}\left[\left(\nu_{i j}-\nu_{i-}\right)^{2} \sigma^{2}\left(\nu_{i j}\right)\right]}{\sum_{i=1}^{m}\left(\nu_{i j}-\nu_{i-}\right)^{2}} .
$$

Accuracy of determining a relative closeness of the alternative to the ideal solution. Relative closeness to the ideal solution of each alternative is determined according to Eq. 12 and its partial derivatives are as follows:

$$
\begin{aligned}
\frac{\partial C_{j}}{\partial S_{j-}} & =\frac{S_{j+}}{\left(S_{j^{*}}+S_{j-}\right)^{2}}, \\
\frac{\partial C_{j}}{\partial S_{j+}} & =-\frac{S_{j-}}{\left(S_{j^{*}}+S_{j-}\right)^{2}} .
\end{aligned}
$$


Then, the variance of the relative closeness can be expressed in the following way:

$$
\sigma^{2}\left(C_{j^{*}}\right)=\frac{S_{j^{*}}^{2}+\sigma^{2}\left(S_{j-}\right)+S_{j-}^{2}+\sigma^{2}\left(S_{j+}\right)}{\left(S_{j^{*}}+S_{j-}\right)^{4}} .
$$

Confidence intervals of the relative closeness with the probability $p=1-q$ (Ross, 2004) are as follows:

$$
C_{j^{*}}-t_{q} \sigma\left(C_{j^{*}}\right) \leqslant C_{j^{*}} \leqslant C_{j^{*}}+t_{q} \sigma\left(C_{j^{*}}\right),
$$

where $t_{q}$ is a multiplier depending on the distribution law of errors and on the credibility level $q . t_{q}=1.96$ in the case of normal distribution with the credibility $q=0.05$.

Based on the developed algorithm, we can state that true values of relative closeness with the probability $p=1-q$ are obtained within the limits of Eq. 26 .

\section{An Example of the Proposed Methodology's Application for Making Construction Management Decisions}

\subsection{Description of the Problem and Ranking of Decision Alternatives}

A computational experiment is presented to illustrate similarities and differences of ranking results by applying TOPSIS and both the normalization methods in a particular situation. In the case study presented here, revitalization of derelict and mismanaged buildings in Lithuania's rural areas was analysed. A sustainable development approach was used for identifying the effective trends of abandoned buildings' development. For this purpose, a set of criteria was developed according to the principles of sustainable development and is one that takes into account some of the local peculiarities (Antucheviciene, 2003; Antucheviciene and Zavadskas, 2004).

In this paper, the above-mentioned criteria system was adapted to multiple criteria decision-making and for calculations that were performed to determine the priorities of buildings' redevelopment alternatives. In the present case study, three alternatives and fifteen criteria were considered. The alternatives included the reconstruction of rural buildings and adapting them for production or commercial activities (alternative $A_{1}$ ), for farming (alternative $A_{2}$ ) or demolition and recycling of the demolished waste (alternative $A_{3}$ ). The following criteria with different dimensions were taken into consideration, including the average soil fertility grade in the area $a_{1}$ (points), quality of life of the local population $a_{2}$ (points), population's activity index $a_{3}(\%)$, GDP in proportion to the average GDP of the country $a_{4}(\%)$, material investments in the area $a_{5}$ (Lt per inhabitant), foreign investments in the area $a_{6}\left(\mathrm{Lt} \times 10^{3}\right.$ per inhabitant), building's redevelopment costs $a_{7}$ $\left(\mathrm{Lt} \times 10^{6}\right)$, income growth of the local population $a_{8}\left(\mathrm{Lt} \times 10^{6} /\right.$ year), increase of sales in the area $a_{9}(\%)$, growth of employment $a_{10}(\%)$, state income from business and property taxes $a_{11}$ (Lt $\times 10^{6}$ per year), business outlook $a_{12}$ (points), difficulties of purpose-built changes $a_{13}$ (points), degree of contamination $a_{14}$ (points), attractiveness of the countryside (i.e., image, landscape, etc.) $a_{15}$ (points). The criteria $a_{2}, a_{7}, a_{13}$ and $a_{14}$ were 
associated with the cost (their smaller value was better), while the remaining attributes were associated with benefit criteria (their greater value was better).

A number of different problems were formulated for the comparative analysis of the results that were obtained in the multi-criteria approach. Six initial decision-making matrices were formed. These matrices consisted of uniform criteria systems describing the regeneration alternatives of rural buildings. The values of the criteria varied in different areas, depending on the particular restoration alternatives of the derelict buildings and their environment.

A multiple criteria analysis was performed using TOPSIS that was based on vector and linear normalization methods for the initial criteria values' transformation (Eqs. 5, 7-12 and Eqs. 6-12, respectively). The results of the multi-criteria analysis are presented in Table 1. Moreover, utility degree of alternatives was measured. The degree of utility is determined by comparison the relative value of the alternative analyzed with the best one and, accordingly, it ranges from $0 \%$ to $100 \%$ (see values in Table 1).

It was found that the priority order of the alternatives was not always the same for a particular problem when different criteria values' normalization methods were applied. Therefore, a comparative analysis of the obtained results was performed.

\subsection{Analysis of the Results: the Influence of a Normalization Method on the Ranking of Alternatives}

Dependence of the accuracy of the results on the method applied to the criteria values' normalization in the framework of TOPSIS is evaluated according to the algorithm presented in Chapter 2. Multi-criteria solutions of several buildings' redevelopment problems (Table 1) are analysed and experimental calculations are performed, assuming the standard deviations of the initial data $\sigma\left(a_{i}\right)$ to be approximately equal to 2 and 5 percent of an average criteria value. The standard deviations of the relative closeness of the alternatives to the ideal solution $\sigma\left(C_{j^{*}}\right)$ are determined for TOPSIS by applying vector and linear criteria values' normalization (Eqs. 13-15, 17-25). Confidence intervals of the relative closeness to the ideal solution with the probability $p=95$ percent are measured and based on Eq. 26 (Table 1). Calculated relative closeness of the alternatives to the ideal solution and confidence intervals, when the standard deviations of the initial data to be approximately equal to 5 percent of an average criteria value, are presented in Fig. 1.

As demonstrated by this calculation experiment, then the relative significances of the alternatives that were considered to be approximately equal in Table 1 (the difference of relative closeness or utility degree of alternatives ranging from 1 to 3 percent) can be considered identical within the accepted limits of their calculation accuracy. In fact, multi-criteria evaluation results can be considered identical if the standard deviations of the initial data make up 2 percent of the average criteria value in the present analysis. Assuming that some information is hardly measurable and some of the criteria values are predicted, it is possible to state that the initial data standard deviations of 2 percent are practically unavoidable. 
Table 1

The priority order of buildings' redevelopment alternatives and accuracy of relative significance of alternatives

\begin{tabular}{|c|c|c|c|c|c|c|c|c|c|c|c|c|c|}
\hline \multirow[b]{2}{*}{ Problem } & \multirow[b]{2}{*}{$\begin{array}{c}\text { Relative } \\
\text { significance }\end{array}$} & \multirow[b]{2}{*}{$\begin{array}{l}\text { Utility } \\
\text { degree }\end{array}$} & \multicolumn{2}{|c|}{ Confidence intervals } & \multirow[b]{2}{*}{$\begin{array}{c}\text { Relative } \\
\text { significance }\end{array}$} & \multirow[b]{2}{*}{$\begin{array}{l}\text { Utility } \\
\text { degree }\end{array}$} & \multicolumn{2}{|c|}{ Confidence intervals } & \multirow[b]{2}{*}{$\begin{array}{c}\text { Relative } \\
\text { significance }\end{array}$} & \multirow[b]{2}{*}{$\begin{array}{l}\text { Utility } \\
\text { degree }\end{array}$} & \multicolumn{2}{|c|}{ Confidence intervals } & \multirow[b]{2}{*}{$\begin{array}{l}\text { Ranking } \\
\text { order* }^{*}\end{array}$} \\
\hline & & & $\begin{array}{c}\text { standard } \\
\text { deviations } \\
\text { of initial } \\
\text { data } 2 \%\end{array}$ & $\begin{array}{c}\text { standard } \\
\text { deviations } \\
\text { of initial } \\
\text { data 5\% }\end{array}$ & & & $\begin{array}{c}\text { standard } \\
\text { deviations } \\
\text { of initial } \\
\text { data } 2 \%\end{array}$ & $\begin{array}{c}\text { standard } \\
\text { deviations } \\
\text { of initial } \\
\text { data 5\% }\end{array}$ & & & $\begin{array}{c}\text { standard } \\
\text { deviations } \\
\text { of initial } \\
\text { data } 2 \%\end{array}$ & $\begin{array}{c}\text { standard } \\
\text { deviations } \\
\text { of initial } \\
\text { data 5\% }\end{array}$ & \\
\hline \multicolumn{14}{|c|}{ TOPSIS based on vector normalization } \\
\hline \multicolumn{5}{|c|}{$A_{1}$} & \multicolumn{4}{|c|}{$A_{2}$} & \multicolumn{4}{|c|}{$A_{3}$} & \\
\hline A & 0.6134 & $100 \%$ & $\begin{array}{l}0.6070 \\
0.6198\end{array}$ & $\begin{array}{l}0.5974 \\
0.6294\end{array}$ & 0.4141 & $67 \%$ & $\begin{array}{l}0.4045 \\
0.4237\end{array}$ & $\begin{array}{l}0.3901 \\
0.4381\end{array}$ & 0.3629 & $59 \%$ & $\begin{array}{l}0.3541 \\
0.3717\end{array}$ & $\begin{array}{l}0.3409 \\
0.3849\end{array}$ & $A_{1} \succ A_{2} \succ A_{3}$ \\
\hline B & 0.5316 & $100 \%$ & $\begin{array}{l}0.5244 \\
0.5388\end{array}$ & $\begin{array}{l}0.5136 \\
0.5496\end{array}$ & 0.4943 & $92 \%$ & $\begin{array}{l}0.4835 \\
0.5051\end{array}$ & $\begin{array}{l}0.4673 \\
0.5213\end{array}$ & 0.3618 & $68 \%$ & $\begin{array}{l}0.3522 \\
0.3714\end{array}$ & $\begin{array}{l}0.3378 \\
0.3858\end{array}$ & $A_{1} \succ A_{2} \succ A_{3}$ \\
\hline $\mathrm{C}$ & 0.5020 & $89 \%$ & $\begin{array}{l}0.4948 \\
0.5092\end{array}$ & $\begin{array}{l}0.4840 \\
0.5200\end{array}$ & 0.5649 & $100 \%$ & $\begin{array}{l}0.5557 \\
0.5741\end{array}$ & $\begin{array}{l}0.5419 \\
0.5879\end{array}$ & 0.4561 & $82 \%$ & $\begin{array}{l}0.4473 \\
0.4649\end{array}$ & $\begin{array}{l}0.4341 \\
0.4781\end{array}$ & $A_{2} \succ A_{1} \succ A_{3}$ \\
\hline $\mathrm{D}$ & 0.6053 & $100 \%$ & $\begin{array}{l}0.5985 \\
0.6121\end{array}$ & $\begin{array}{l}0.5883 \\
0.6223\end{array}$ & 0.4469 & $74 \%$ & $\begin{array}{l}0.4377 \\
0.4561\end{array}$ & $\begin{array}{l}0.4239 \\
0.4699\end{array}$ & 0.4561 & $75 \%$ & $\begin{array}{l}0.4473 \\
0.4649\end{array}$ & $\begin{array}{l}0.4341 \\
0.4781\end{array}$ & $A_{1} \succ A_{3} \approx A_{2}$ \\
\hline E & 0.5868 & $100 \%$ & $\begin{array}{l}0.5820 \\
0.5916\end{array}$ & $\begin{array}{l}0.5748 \\
0.5988\end{array}$ & 0.4335 & $73 \%$ & $\begin{array}{l}0.4267 \\
0.4403\end{array}$ & $\begin{array}{l}0.4165 \\
0.4505\end{array}$ & 0.3824 & $64 \%$ & $\begin{array}{l}0.3744 \\
0.3904\end{array}$ & $\begin{array}{l}0.3624 \\
0.4024\end{array}$ & $A_{1} \succ A_{2} \succ A_{3}$ \\
\hline F & 0.6079 & $100 \%$ & $\begin{array}{l}0.6019 \\
0.6139\end{array}$ & $\begin{array}{l}0.5929 \\
0.6229\end{array}$ & 0.4726 & $77 \%$ & $\begin{array}{l}0.4626 \\
0.4826\end{array}$ & $\begin{array}{l}0.4476 \\
0.4976\end{array}$ & 0.3613 & $59 \%$ & $\begin{array}{l}0.2893 \\
0.4333\end{array}$ & $\begin{array}{l}0.3433 \\
0.3793\end{array}$ & $A_{1} \succ A_{2} \succ A_{3}$ \\
\hline \multicolumn{14}{|c|}{ TOPSIS based on linear normalization } \\
\hline \multicolumn{5}{|c|}{$A_{1}^{\prime}$} & \multicolumn{4}{|c|}{$A_{2}^{\prime}$} & \multicolumn{4}{|c|}{$A_{3}^{\prime}$} & \\
\hline A & 0.6262 & $100 \%$ & $\begin{array}{l}0.6078 \\
0.6446\end{array}$ & $\begin{array}{l}0.5802 \\
0.6722\end{array}$ & 0.4232 & $68 \%$ & $\begin{array}{l}0.4044 \\
0.4420\end{array}$ & $\begin{array}{l}0.3762 \\
0.4702\end{array}$ & 0.3718 & $60 \%$ & $\begin{array}{l}0.3554 \\
0.3882\end{array}$ & $\begin{array}{l}0.3308 \\
0.4128\end{array}$ & $A_{1}^{\prime} \succ A_{2}^{\prime} \succ A_{3}^{\prime}$ \\
\hline B & 0.4890 & $91 \%$ & $\begin{array}{l}0.4766 \\
0.5014\end{array}$ & $\begin{array}{l}0.4580 \\
0.5200\end{array}$ & 0.5352 & $100 \%$ & $\begin{array}{l}0.5212 \\
0.5492\end{array}$ & $\begin{array}{l}0.5002 \\
0.5702\end{array}$ & 0.3721 & $69 \%$ & $\begin{array}{l}0.3585 \\
0.3857\end{array}$ & $\begin{array}{l}0.3381 \\
0.4061\end{array}$ & $A_{2}^{\prime} \succ A_{1}^{\prime} \succ A_{3}^{\prime}$ \\
\hline $\mathrm{C}$ & 0.4591 & $72 \%$ & $\begin{array}{l}0.4455 \\
0.4727\end{array}$ & $\begin{array}{l}0.4251 \\
0.4931\end{array}$ & 0.6360 & $100 \%$ & $\begin{array}{l}0.6236 \\
0.6484\end{array}$ & $\begin{array}{l}0.6050 \\
0.6670\end{array}$ & 0.4840 & $75 \%$ & $\begin{array}{l}0.4704 \\
0.4976\end{array}$ & $\begin{array}{l}0.4500 \\
0.5180\end{array}$ & $A_{2}^{\prime} \succ A_{3}^{\prime} \approx A_{1}^{\prime}$ \\
\hline D & 0.6151 & $100 \%$ & $\begin{array}{l}0.6039 \\
0.6263\end{array}$ & $\begin{array}{l}0.5871 \\
0.6431\end{array}$ & 0.4642 & $74 \%$ & $\begin{array}{l}0.4498 \\
0.4786\end{array}$ & $\begin{array}{l}0.4282 \\
0.5002\end{array}$ & 0.4840 & $77 \%$ & $\begin{array}{l}0.4704 \\
0.4976\end{array}$ & $\begin{array}{l}0.4500 \\
0.5180\end{array}$ & $A_{1}^{\prime} \succ A_{3}^{\prime} \approx A_{2}^{\prime}$ \\
\hline $\mathrm{E}$ & 0.4715 & $87 \%$ & $\begin{array}{l}0.4199 \\
0.5231\end{array}$ & $\begin{array}{l}0.3425 \\
0.6005\end{array}$ & 0.3720 & $70 \%$ & $\begin{array}{l}0.3292 \\
0.4148\end{array}$ & $\begin{array}{l}0.2650 \\
0.4790\end{array}$ & 0.5306 & $100 \%$ & $\begin{array}{l}0.4822 \\
0.5790\end{array}$ & $\begin{array}{l}0.4096 \\
0.6516\end{array}$ & $A_{3}^{\prime} \succ A_{1}^{\prime} \succ A_{2}^{\prime}$ \\
\hline F & 0.6369 & $100 \%$ & $\begin{array}{l}0.6118 \\
0.6557\end{array}$ & $\begin{array}{l}0.5899 \\
0.6839\end{array}$ & 0.5523 & $86 \%$ & $\begin{array}{l}0.5279 \\
0.5767\end{array}$ & $\begin{array}{l}0.4913 \\
0.6133\end{array}$ & 0.3517 & $55 \%$ & $\begin{array}{l}0.3301 \\
0.3733\end{array}$ & $\begin{array}{l}0.2977 \\
0.4057\end{array}$ & $A_{1}^{\prime} \succ A_{2}^{\prime} \succ A_{3}^{\prime}$ \\
\hline
\end{tabular}

* Primary ranking results when ranking accuracy was not evaluated. 
In the problem $\mathrm{C}$ the alternatives $A_{1}\left(A_{1}^{\prime}\right)$ and $A_{3}\left(A_{3}^{\prime}\right)$ were ranked differently by taking into account the calculated relative significance $C_{j^{*}}$ in the case of vector and linear normalization (Table 1). When taking into consideration the standard deviation of the $C_{j^{*}}$ estimation, the priority order of the alternatives remains unchanged for the case of vector normalization with the probability $p=95$ percent. However, as shown in Fig. 1, the confidence intervals of the alternatives $A_{1}^{\prime}$ and $A_{3}^{\prime}$ partially overlap in the case of linear normalization. $C_{1^{*}}$ and $C_{3^{*}}$ can be considered identical within the accepted limits of their calculation's accuracy. Similarly, it is possible to state that the results of the multi-criteria analysis can be considered identical in the presented case (problem C) when both criteria values' normalization methods are applied.

The data obtained by using the TOPSIS method and based on linear normalization were less accurate as compared to the TOPSIS results that were based on vector normalization of the criteria values. In some cases, the utility degree of buildings' redevelopment alternatives that differ by $8-17$ percent and more can be considered identical with the probability $p=95$ percent in a case of linear normalisation, if the standard deviations of the initial data range from 2 to 4 percent. In one of the cases analysed (problem E), the relative significances of alternatives $A_{2}^{\prime}$ and $A_{3}^{\prime}$ can be considered identical within the specified limits of calculation accuracy with the given initial data standard deviation of 4 percent even when the utility degree of alternatives differ by 30 percent. The above matching may be accounted for by the particular structure of the initial data as was found in this particular case. However, the above features cannot be observed in the case of vector normalization. For the initial data standard deviations ranging within 5 percent, the maximum 8 percent difference of the utility degree of the alternatives can be considered identical within the limits of specified calculation's accuracy with the probability $p=95$ percent, when the vector normalization is used as it was in the present research.

In problem E, the priority order of the alternatives when applying TOPSIS and based on vector and linear criteria values' transformation methods is considered to be different (Table 1 and Fig. 1), if the accuracy of its determination is not taken into account. Then, according to the proposed methodology, the relative importance of the alternatives as a function of the criteria values is determined and the confidence intervals are calculated. The results of calculations show that all confidence intervals partially overlap with the probability $p=95$ percent in problem E (Fig. 1). Therefore, in this case (problem E), the establishment of the effective alternative should be based on TOPSIS and using vector normalization. If a linear normalization is applied and the initial data standard deviation ranging within 5 percent is set as a precondition, then the calculated relative closeness of the alternatives to the ideal solution can be considered identical, providing there is no information on the priorities of alternative solutions.

To establish if the standard deviations of determining the relative closeness of the alternatives depend on the absolute values of the relative closeness, the correlation coefficients between the absolute values of the parameters and their standard deviations are calculated. For vector normalization, the correlation coefficient is equal to -0.57 , indicating a statistically significant and moderately strong relationship between the parameters. In the case of linear normalization, the correlation coefficient equals -0.17 and is statistically insignificant. The described analysis indicates that larger parameter's values are 

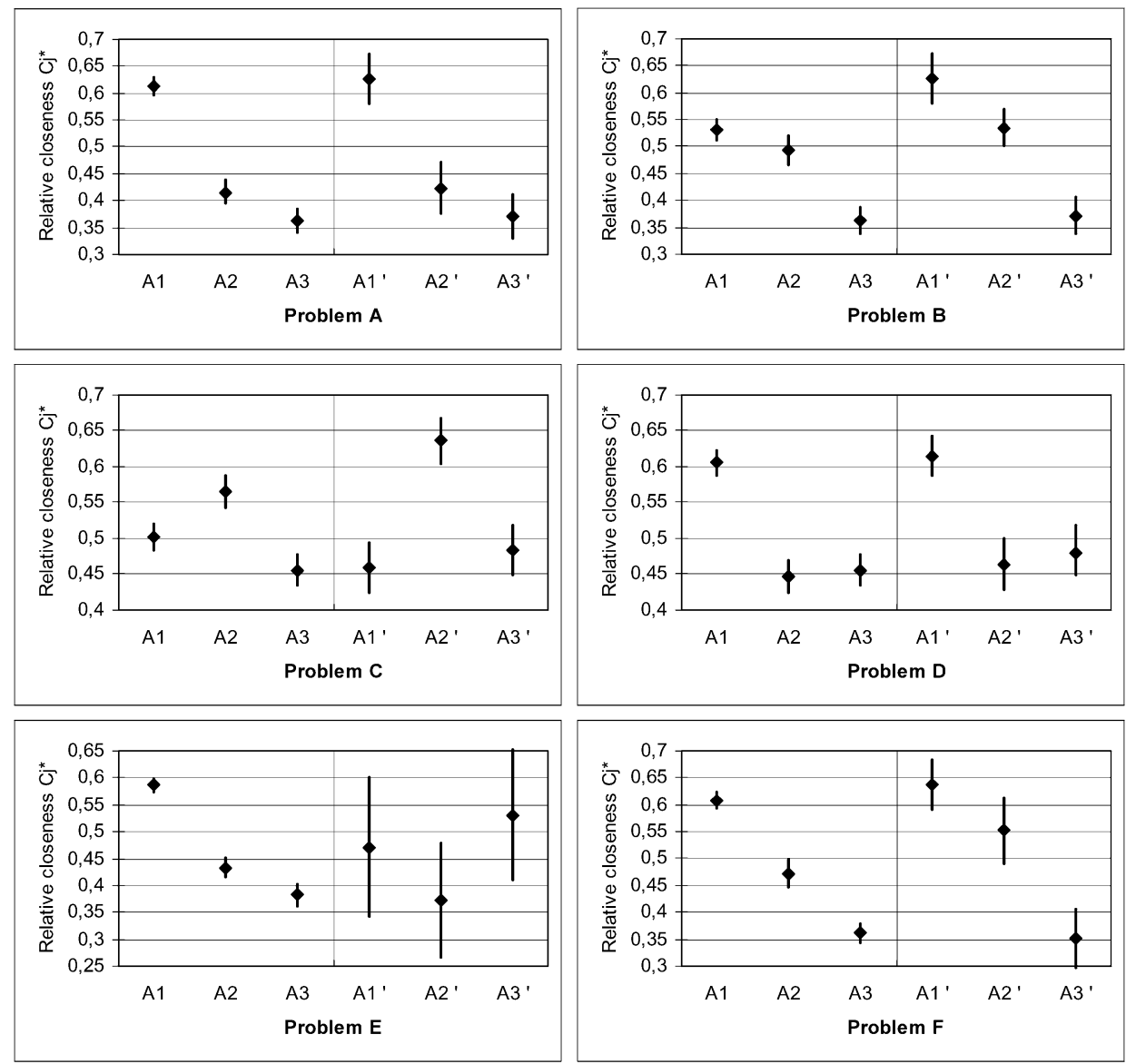

Fig. 1. The relative closeness of the alternatives to the ideal solution and confidence intervals when vector and linear normalization is applied:

$\checkmark$ relative closeness to the ideal solution;

I confidence interval of relative closeness with the probability $p=95$ per cent.

more accurately estimated as compared to smaller values, when the parameters values' transformation through normalization of the vectors is applied. However, in the case of linear normalization, this dependence cannot be observed.

When applying vector normalization, the statistical relationship between the parameter's values and their standard deviations can be described by the linear regression model as follows:

$$
\sigma\left(C_{j^{*}}\right)=0.0179-0.0169 C_{j^{*}},
$$

and expressed by a second-order polynomial model in the following way:

$$
\sigma\left(C_{j^{*}}\right)=-0.0250+0.1673 C_{j^{*}}-0.1841 C_{j^{*}}^{2} .
$$




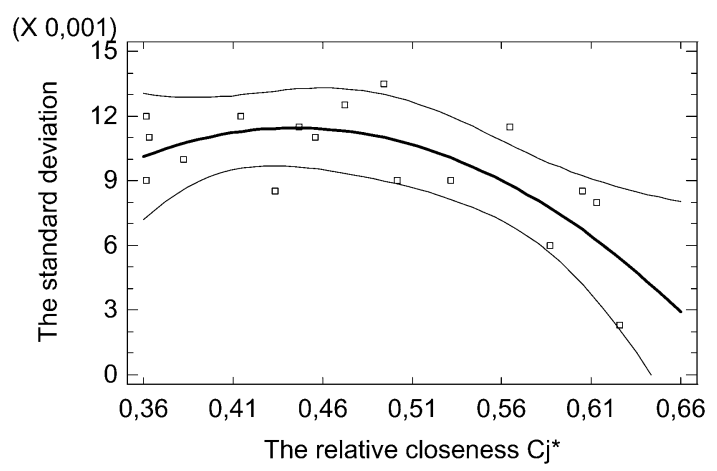

Fig. 2. Distribution of standard deviations of relative closeness to the ideal solution in the case of vector criteria values' normalization:

$\square$ standard deviations;

_ graph of dependence of standard deviations on relative closeness;

_ confidence interval of dependence of standard deviations on relative closeness with the probability $p=99$ percent.

The standard deviation of the estimate implies that the standard deviation of the residuals is 0.0023 and the probability of adequacy of the model to experimental results is $p=0.986$ in the case of the linear model. When the model of standard deviations is described by a second-order polynomial equation, the same values are 0.0015 and $p=0.998$, respectively. Therefore, it is possible to state that both models are adequate for the experimental results, with the probability $p>0.95$. However, the standard deviation of the estimate in the second-order polynomial model is by about 35 percent lower as compared to the linear model.

In the case of linear normalization, empirical relationships between the parameter's values and their standard deviations can be described by the first-order equation:

$$
\sigma\left(C_{j^{*}}\right)=0.0399-0.0273 C_{j^{*}}
$$

The standard deviation of values in the model is 0.0162 and probability of the applied model's adequacy to experimental results is $p=0.479$. Therefore, it is possible to state that the model (Eq. 29) is not adequate to experimental results in this case. No statistically significant relations between the values of the relative closeness of the alternatives to the ideal solution and the standard deviations can be observed according to the above model.

The relations between the values and their standard deviations in the case of vector normalization are presented in Fig. 2, while the case of linear normalization is shown in Fig. 3 (when the standard deviations of the initial data to be approximately equal to 5 percent of an average criteria value).

One can see that, in the case of linear normalization, the values of the standard deviations are to 3-5 times more those of vector normalization for the considered example. In the case of linear normalization, the stochastic distribution of the standard deviations is also higher. However, when the criteria values are transformed through a normalization 


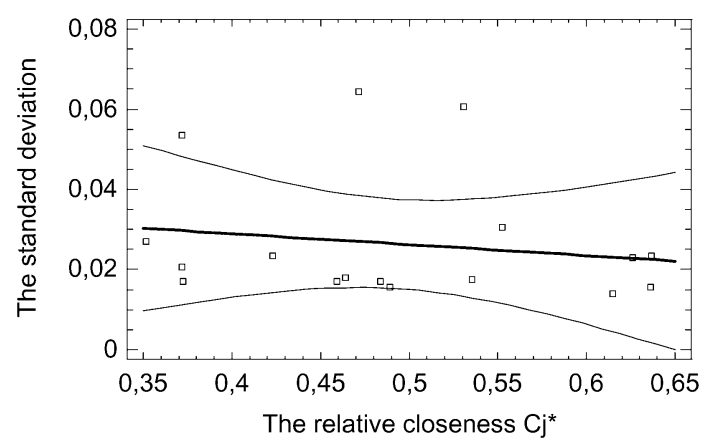

Fig. 3. Distribution of standard deviations of relative closeness to the ideal solution in the case of linear criteria values' normalization:

$\square$ standard deviations;

- graph of dependence of standard deviations on relative closeness;

_ confidence interval of dependence of standard deviations on relative closeness with the probability $p=99$ percent

of vectors, the standard deviations spread within a narrower zone. The above zone variation follows the variation law of dependence between the parameter's values and their standard deviations (Fig. 2).

\section{Conclusions}

In multi-criteria optimisation problems the differences of the priority order of alternatives from the accepted probability can be verified by evaluating the accuracy of the results obtained as a function of errors of the initial criteria values.

The methodology for measuring the accuracy of the relative significance of the alternatives as a function of the criteria values was developed.

An example was presented and the accuracy of data obtained in multi-criteria analysis of derelict buildings' rational management by applying the TOPSIS method that is based on vector and linear normalization, was assessed.

It was determined that the relative closeness of the alternatives to the ideal solution with the difference ranging from 1 to 3 percent, can be considered identical with the probability $p=95$ percent when applying both methods of the initial criteria values' transformation within the specified limits of the calculation's accuracy, if the standard deviations of initial data make up 2 percent of the average criteria value.

The accuracy of results in multi-criteria decisions is influenced not only by errors of the initial criteria values but also depends on solution techniques and transformation methods of the initial criteria values used.

In the case of presented computational experiment, the values expressing relative closeness of the alternatives to the ideal solution yielded by TOPSIS and based on linear normalization were assessed to be approximately 2.3 times less accurate than the data obtained by the method based on vector normalization of the criteria values. 
In terms of the standard deviations and confidence intervals of the relative closeness to the ideal solution, the difference in the relative significance of the alternatives equal to 0.01 can be considered statistically insignificant with the probability $p=95$ percent, if the standard deviations of the initial data make up about 2 percent of the average criteria value as in the case of linear normalization.

In the case of vector normalization, the difference of the relative significance equal to 0.01 can be considered statistically insignificant if the standard deviations of the initial data reach $4-5$ percent.

When TOPSIS is based on linear normalization and applied, the standard deviations of the initial data making up about 4-5 percent may lead to identical ranking results with the probability $p=95$ percent, even if the difference of the relative significance is 0.15 .

It was determined that the standard deviations of the relative closeness to the ideal solution depend on the absolute values of relative closeness as in the case of vector normalization. The standard deviations of larger absolute values are larger, and vice versa, when the initial data standard deviations remain the same. In the case of linear normalization, the standard deviations of relative closeness to the ideal solution do not depend on its absolute values.

\section{Acknowledgements}

The authors are grateful to the anonymous referee for the comprehensive review and constructive comments.

\section{References}

Antucheviciene, J. (2003). Principles of revitalization of derelict rural buildings. Journal of Civil Engineering and Management, 9(4), 225-233.

Antucheviciene, J., and E.K. Zavadskas (2004). Rational use of derelict buildings from the viewpoint of sustainable development. International Journal of Environment and Sustainable Development, 3(2), 96-110.

Brauers, W.K. (2004). Optimization Methods for a Stakeholder Society. A Revolution in Economic Thinking by Multiobjective Optimization. Kluwer Academic Publishers, Boston.

Chen, S.J., and C.L. Hwang (1991). Fuzzy multiple attribute decision making methods and applications. Lecture Notes in Economics and Mathematical Systems, 375, Springer-Verlag, Berlin.

Cheng, S., C.W. Chan and G.H. Huang (2003). An integrated multi-criteria decision analysis and inexact mixed integer linear programming approach for solid waste management. Engineering Applications of Artificial Intelligence, 16(5-6), 543-554.

Dejus, T. (2002). The model of determining the sensitivity of elements of multiple criteria evaluation methods. Journal of Civil Engineering and Management, 8(4), 263-268.

Deng, H., Ch.H. Yeh and R.J. Willis (2000). Inter-company comparison using modified TOPSIS with objective weights. Computers and Operations Research, 27(10), 963-973.

Dzemyda, G., and V. Saltenis (1994). Multiple criteria decision support system: methods, user's interface and applications. Informatica, 5(1-2), 31-42.

Dzemyda, G., and T. Petkus (2001). Application of computer network to solve the complex applied multiple criteria optimization problems. Informatica, 12(1), 45-60.

Fiedler, K., F. Peldschus and E.K. Zavadskas (1986). Methoden der Bautechnologischen Entscheidung. Technische Hochschule Leipzig. 
Figueira, J., S. Greco and M. Ehrgott (Eds.) (2005). Multiple Criteria Decision Analysis. State of the Art Surveys. Springer.

Gogus, O., and T.O. Boucher (1997). A consistency test for rational weights in multi-criterion decision analysis with fuzzy pairwise comparisons. Fuzzy Sets and Systems, 86(2), 129-138.

Greening, L.A., and S. Bernow (2004). Design of coordinated energy and environmental policies: use of multicriteria decision-making. Energy Policy, 32(6), 721-735.

Guitouni, A., and J.M. Martel (1998). Tentative guidelines to help choosing an appropriate MCDA method. European Journal of Operational Research, 109(2), 501-521.

Hwang, C.L., and K. Yoon (1981). Multiple Attribute Decision Making Methods and Applications. SpringerVerlag, Berlin.

Jüttler, H. (1966). Untersuchungen zur Fragen der Operationsforschung und ihrer Anvendungsmöglichkeiten auf ökonomische Problemstellungen unter besonderer Berücksichtigung der Spieltheorie. Dissertation A an der Wirtschaftswissenschsftlichen Fakultät der Humbolt-Universität Berlin.

Kaklauskas, A., E.K. Zavadskas and S. Raslanas (2005). Multivariant design and multiple criteria analysis of building refurbishments. Energy and Buildings, 37, 361-372.

Kaklauskas, A., E.K. Zavadskas, S. Raslanas, R. Ginevicius, A. Komka and P. Malinauskas (2006). Selection of low-e windows in retrofit of public buildings by applying multiple criteria method COPRAS: A Lithuanian case. Energy and Buildings, 38, 354-362.

Kalika, V.I., and G. Rossinsky (2003). Methodology of multi-criteria decision-making accounting for uncertainty and some applications. International Journal of Management and Decision Making, 4(2/3), 240-271.

Kettani, O., B. Aouni and J.M. Martel (2004). The double role of the weight factor in the goal-programming model. Computers \& Operations Research, 31(11), 1833-1845.

Körth, H. (1969). Zur Berücksichtigung mehrer Zielfunktionen bei der Optimierung von Produktionsplanen. Mathematik und Wirtschaft, 6, 184-201.

Lai, Y.J., and C.L. Hwang (1994). Fuzzy Multiple Objective Decision Making: Methods and Applications. Springer-Verlag, Berlin.

Lin, L.Ch., and G.P. Sharp (1999). Application of the integrated framework for the plant layout evaluation problem. European Journal of Operational Research, 116(1), 118-138.

Montanari, R. (2004). Environmental efficiency analysis for enel thermo-power plants. Journal of Cleaner Production, 12(4), 403-414.

Opricovic, S., and G.H. Tzeng (2002). Multicriteria planning of post-earthquake sustainable reconstruction. Computer-Aided Civil and Infrastructure Engineering, 17(3), 211-220.

Opricovic, S., and G.H. Tzeng (2004). Compromise solution by MCDM methods: A comparative analysis of VIKOR and TOPSIS. European Journal of Operational Research, 156(2), 445-455.

Peldschus, F., E. Vaigauskas and E.K. Zavadskas (1983). Technologische Entscheidungen bei der Berücksichtigung mehrerer Ziele. Bauplanung-Bautechnik, 37(4), 173-175.

Peldschus, F. (2001). Research on the sensitivity of multi-criteria evaluation methods. Statyba (Civil Engineering), 7(4), 276-281 (in German).

Peldschus, F. and E.K. Zavadskas (2005). Fuzzy matrix games multi-criteria model for decision-making in engineering. Informatica, 16(1), 107-120.

Pöyhönen, M., H. Vrolijk and R.P. Hämäläinen (2001). Behavioral and procedural consequences of structural variation in value trees. European Journal of Operational Research, 134(1), 216-227.

Raju, K.S., and C.R.S. Pillai (1999). Multicriterion decision making in river basin planning and development. European Journal of Operational Research, 112(2), 249-257.

Ross, Sh.M. (2004). Introduction to Probability and Statistics for Engineers and Scientists. Elsevier Academic Press.

Saaty, T.L. (2006). Rank from comparisons and from ratings in the analytic hierarchy/network processes. $E u$ ropean Journal of Operational Research, 168(2), 557-570.

Sarkis, J. (2000). A comparative analysis of DEA as a discrete alternative multiple criteria decision tool. European Journal of Operation Research, 123(3), 543-557.

Schneeweiss, C. (1991). Planung, Systemanalytische und Entscheidungstheoretische Grundlagen. Berlin, Germany.

Tong, L.I., Ch.H. Wang, Ch.Ch. Chen and Ch.T. Chen (2004). Dynamic multiple responses by ideal solution analysis. European Journal of Operational Research, 156(2), 433-444. 
Triantaphyllou, E. (2000). Multi-criteria Decision Making Methods: a Comparative Study. Kluwer Academic Publishers.

Tsaur, S.H., T.Y. Chang and Ch.H. Yen (2002). The evaluation of airline service quality by fuzzy MCDM. Tourism Management, 23(2), 107-115.

Tzeng, G.H., Ch.W. Lin and S. Opricovic (2005). Multi-criteria analysis of alternative fuel buses for public transportation. Energy Policy, 33(11), 1373-1383.

Vilutiene, T. and E.K. Zavadskas (2003). The application of multi-criteria analysis to decision support for the facility management of a residential district. Journal of Civil Engineering and Management, 9(4), 241-252.

Weitendorf, D. (1976). Beitrag zur Optimierung der räumlichen Struktur eines Gebäudes. Dissertation A, Hochschule für Architektur und Bauwesen, Weimar.

Zavadskas, E.K., F. Peldschus and A. Kaklauskas (1994). Multiple Criteria Evaluation of Projects in Construction. Technika, Vilnius.

Zavadskas, E.K., A. Kaklauskas and N. Kvederyte (2001). Multivariant design and multiple criteria analysis of a building life cycle. Informatica, 12(1), 169-188.

Zavadskas, E.K., L. Ustinovichius, Z. Turskis, F. Peldschus and D. Messing (2002). LEVI 3.0 - multiple criteria evaluation program for construction solutions. Journal of Civil Engineering and Management, 8(3), 184191.

Zavadskas, E.K., L. Ustinovichius and F. Peldschus (2003). Development of software for multiple criteria evaluation. Informatica, 14(2), 259-272.

Zavadskas, E.K., A. Kaklauskas, A. Banaitis and N. Kvederyte (2004). Housing credit access model: The case for Lithuania. European Journal of Operational Research, 155(2), 335-352.

Zavadskas E.K., and J. Antucheviciene (2004). Evaluation of buildings redevelopment alternatives with an emphasis on the multipartite sustainability. International Journal of Strategic Property Management, 8(2), 121-127.

Zeleny, M. (1982). Multiple Criteria Decision Making. McGraw-Hill, New York.

Zimmermann, H.J., and L. Gutsche (1991). Multi-Criteria Analyse. Springer-Verlag. 
E.K. Zavadskas is principal vice-rector of Vilnius Gediminas Technical University, and head of the Dept. of Construction Technology and Management at Vilnius Gediminas Technical University, Vilnius, Lithuania. He has a PhD in building structures (1973) and DrSc (1987) in building technology and management. He is a member of the Lithuanian and several foreign Academies of Sciences. He is Doctore Honoris Causa at Poznan, Saint-Petersburg, Kiev. He is a member of international organisations and has been a member of steering and programme committees at many international conferences. E.K. Zavadskas is a member of editorial boards of several research journals. He is author and co-author of more than 300 papers and a number of monographs in Lithuanian, English, German and Russian. Research interests are: building technology and management, decision-making theory, automation in design and decision support systems.

A. Zakarevicius is professor at the Department of Geodesy and Cadastre at Vilnius Gediminas Technical University, Vilnius, Lithuania. He has a $\mathrm{PhD}$ in technological sciences (1973) and DrSc (2000) in measurement engineering. A. Zakarevicius is author and coauthor of more than 150 papers and author of three monographs. He is a member of a number of international organisations and programmes, a member of the editorial board of a research journal. Research interests are: investigation of the recent geodynamic processes, multiple statistical modelling and processing of measurement results.

J. Antucheviciene is an associate professor at the Department of Construction Technology and Management at Vilnius Gediminas Technical University, Vilnius, Lithuania. She has a master's degree in social sciences and a $\mathrm{PhD}$ in construction engineering. She is author and co-author of a number of refereed journal articles and conference papers on decision-making and construction management. Current research interests are: sustainable development, construction management, multiple criteria analysis and decisionmaking theories. 


\section{Alternatyvu prioritetụ nustatymo daugiakriteriniuose uždaviniuose tikslumas}

Edmundas Kazimieras ZAVADSKAS, Algimantas ZAKAREVIČIUS, Jurgita ANTUCHEVIČIENĖ

Straipsnyje nagrinejjamas alternatyvų prioritetų nustatymo tikslumas daugiakriteriniuose sprendimų uždaviniuose. Parengta metodika alternatyvu santykinio reikšmingumo, kaip alternatyvas apibūdinančių rodiklių reikšmių funkcijos, tikslumui įvertinti. Pateiktas pavyzdys taikant artumo idealiam taškui metodą (TOPSIS), naudojant vektorinį bei tiesinį rodiklių reikšmių normalizavimo būdus. Palyginti daugiakriterinès analizès rezultatai bei jụ tikslumas. 